\title{
Playing at Birth: \\ Samuel R. Delany's Dhalgren
}

\author{
Todd A. Comer
}

\begin{abstract}
A joycean tour de force of a novel, Dhalgren ... stake[s] a better claim than anything else in this country in the last quarter-century (excepting only Gass's Omensetter's Luck and Nabokov's Pale Fire) to a permanent place as one of the enduring monuments of our national literature.-The Libertarian Review (blurb taken from the recent Vintage edition.)
\end{abstract}

This reviewer has missed the point. Or, rather, this reviewer has missed one point of many in his reduction of Dhalgren to a national monument. To be fair, this reduction is the essence of the work of a traditional book review and of much intellectual work. While I do agree that Dhalgren is an "enduring monument of our national literature," I question the absence of scare quotes in the review. In the world of Dhalgren (and some would say, our world) adjectives-like "permanent" and "enduring"—and nouns-like "monument" and "nation"- can only be written under erasure. There is another reading of Delany's novel, a reading which interrupts any simple reduction to a patriotic monument, work of art, or tool of ego creation.

Situating Dhalgren, published in 1975, in the context of the 1960's and early 1970's is difficult to resist. Indeed, Delany has admitted that the

JNT: Journal of Narrative Theory 35.2 (Summer 2005): 172-195. Copyright @ 2005 by JNT: Journal of Narrative Theory. 
"ruins and wrecks" of U.S. cities provided him with his essential material (Edelman). We also know from the same interview that Delany originally envisioned the novel as a series of five novels in which five dissimilar governments would be overthrown by a "group of people just exercising the wonderful world view of the flower children." For African-Americans, the 1960's and 1970's were a period of extreme poverty and racism, as well as a period of great change with so many migrating from the rural south to the industrial north (Zinn 458-459). During this period there were peaceful civil right marches, militant Black Panther actions, anti-war protests, prison riots, and assassinations. Exercising little hyperbole, Howard Zinn describes blacks as "engaging in wild insurrection in a hundred northern cities" in the late 1960's (450). Dhalgren's Bellona, named after the Roman goddess of war, feels like a city torn apart by a race riot, if not a coup d'état. All of which implies that while Delany's original conception altered significantly, his critique of extant political structures remains. Readers of Dhalgren in 1975 would have been incapable of understanding Bellona as anything other than a near analogue of cities recently torn asunder by urban riots.

What follows, then, needs to be understood as involving an ethical critique of concrete political structures and as not simply concerned with the writing of the text before us because, as I will argue, the city along with every subjectival creation is a product of myth. Delany's text interrogates such monumental myths through a representation of the city (and thereby, the subject) as wounded and open to certain ethical possibilities. In its fragmentation Delany's text represents, internally and externally, subjectivity at its limit, which is to say, a "subjectivity" whose assimilative powers have been overwhelmed by the experience of the death of the other, exposing it to community. However, I read Dhalgren first as a way of thinking about how writing can mitigate against the monumentalism of the subject and the subject's myths that obsess after non-relation, eliding that birth or (communal) relation that comes from the outside and others. Dhalgren becomes above all a "novel" which plays at birth, at never getting beyond birth, always coming and never arriving at presence, and, hence, always remaining with others.

Bellona defies description. Indeed, this city seems lost even to perception, "Very few suspect the existence of the city. It is as if not only the media but the laws of perspective themselves have redesigned knowledge 
and perception to pass it by. Rumor says that there is practically no power here. Neither television cameras nor on-the-spot broadcasts function: that such a catastrophe as this should be opaque" (14). There is no law, no social structure, little work, and little sense of time. Much of the population has fled and much of this enormous city has been burnt to the ground. Often the city seems a labyrinth in which streets and landmarks move and shift according to no discernible law. Sometimes there are two moons and sometime only one. Sometimes the sun appears so large that it looks like it is going nova. No one knows why or how Bellona became this way. It could have been a meteor, a fire, the "rape" of a white girl by a black man, a bomb, a riot, an ecological disaster, or something else. Like many things in Dhalgren, this question is never satisfyingly answered. Bellona is a "vague, vague city" (382).

Dhalgren's complexity cannot be understated. Fortunately, Delany has provided a set piece, a microcosm, at the center of his massive novel which provides the reader with a sense of what is at stake in Bellona. Against the horror of Bellona, one person, Mary Richards, described as both bookish and creative, continues to work. According to Mr. Richards:

Mary lives in her world of cooking and cleaning and the children. I come home. And nothing looks . . . I can't describe it. A man's home is supposed to be-well, a place where everything is real, solid, and he can grab hold. In our home, I just don't know. I come in from that terrible world, and I'm in some neverland I just don't believe in. And the less I believe in it, the more it slips. I think it's me, sometimes. Mary's always been a strange woman; she hasn't had it that easy. She tries so hard to be . . . well civilized [. . . ] suddenly you begin to feel she's changing the world into her own ideas. (173)

An exemplary rational subject, Mary makes a project out of the world, creating it in her image (Nancy IC 3). Such is her power that Kid and others conform to her conversational expectations: "she does more than [keep a "nice house']. She keeps us too" which is essentially her way of dispelling the confusion of the Bellonan landscape and reinforcing her identity. 
Bellona's catastrophe is murky. Among the various elements that are paraded as causes - the storm, a shooting, the rioting - a major focus is the violent, consensual, and public sex act that occurs between the young white June Richards and the older black man George Harrison. This act is widely publicized in the Bellona Times. Opposed and yet linked to this public act is a private act, June's alleged murder of her brother. While helping June move a rug to a new apartment, Bobby falls down an elevator shaft. This occurs shortly after he threatens to reveal June's desire to their mother, a revelation that would undermine the tenuous state of propriety in the Richards home. To further substantiate reading this family as a microcosm of Bellona, consider this early conversation between Kid and Milly on the Bellona catastrophe: "when it happened [. . .] it was terrible," she says. Her use of "terrible" reminds Kid of "the way he remembered a man in a brown suit once say 'elevator.' It's that tone, he thought, remembering when it had denuded Tak's speech" (30). When told of Bobby's elevator accident, Mr. Richards exhibits a "lack of expression" which can only re-emphasize how the expressive identity of the solipsistic subject is undermined by that which it cannot cognize (248). Bobby's elevator accident microcosmically grounds this larger catastrophic event and the denuding that is characteristic of Bellona.

In the midst of the work of myth, such moments of horror, leading to this inexpressiveness, are smoothed-over. Directly before Bobby's death, Mrs. Richards describes how the "shrieking" on the part of her neighbors made "mak[ing] a home" impossible (original's emphasis; 227). The move to another apartment is meant to remedy the noise problem, but instead, as she feared, "a space, a gap, a crack [appears] in which some terrible thing might get in and destroy it, us, my home." This is made less abstract in a conversation following Bobby's accident in which Mrs. Richards tells how a "huge crack" once appeared in June's ceiling and how it took management three months to repair it. She explains that when such things happen all she can do is continue making a "good home, where nothing can hurt [her spouse]" (my emphasis; 246). By "nothing," we may read any thing that would undermine subjectivity. Briefly, death is that no-thing that concerns her. It follows that one of the most common refrains in the novel is Kid's recognition that he is going to die (372). It is such a recognition, such a crack or wound in the family being, that Mrs. Richards concerns herself with; she, however, cannot face this fear, but uses others to obscure it. 
When Kid argues for her to change and says, "But if everything outside has changed-," she responds, then "I have to be [. . .] stronger inside" (original's emphasis; 227). This means, as a later conversation indicates, that for her the "outside" in a sense is not "real" at all (244-245). When, for instance, her spouse leaves the building for work, he does not go "anywhere" because, she explains, there is no place to go. The outside is simply beyond her comprehension, or a projection of a narcissistic self (which amounts to the same thing). Just as she feared, a "space" does appear and this is the spacing of what Jean-Luc Nancy, following Heidegger, terms being-with, or Mitsein that resists her incessant project. Nancy, in particular is important here as he addresses so many of the key issues of Delany's text: the nature of subjectivity, the subject's relation to myth and violence, and, finally, community as that which occurs at the moment of myth's interruption.

While this will require further nuancing, the important point to gather at this juncture is that subjectivity is grounded in the control of alterity. Richards controls and assimilates the world so that it no longer horrifies her. In this imminently rational process, she creates an inside and an outside, the most basic sort of representation or myth to map the world. However, as Nancy argues, the experience of the death of an other "irremediably exceeds the resources of a metaphysics of the subject" (IC 14). As this is an experience that we can have no knowledge of, the border that separates subjectivity from the outside, alterity, is violated. Bobby's fall through space and his bloody return in the arms of Kid highlights how very real the outside is, undermining Mrs. Richard's solipsistic self. The move from the $17^{\text {th }}$ to the $19^{\text {th }}$ floor was supposed to be a controlled, upward reorientation that would ultimately better preserve the family. It is instead much more "cost[ly]" than expected, leading to less a controlled movement than to an absolute spatial hemorrhaging in which the family being is torn and exposed to all the difference it hopes to elide. Mrs. Richards is grief-stricken (246).

The metaphor that most succinctly links the Richards, Bellona, and writing is that of wounding. Bobby's fall leaves him viscerally exposed to the outside - not a subjectival outside, but the outside that the subject's bordering of the world hopes to tame. The same is true for the larger family being in the aftermath of his death, as it works to create a tidy separation between the inside and outside and close the crack in the ceiling, if 
you will. Mrs. Richards quickly begins to heal this more immediate wound. By contrast, it is Kid who retrieves the body, looking just as horrific as Bobby, who cannot easily salve this wound. Like Joyce's Finnegans Wake, Dhalgren is circular. It ends and begins with the following: " [ . . . I have come to / to wound the autumnal city." In Jean Mark Gawron's path-breaking article, he describes this "come to" as the "coming to" of consciousness and the repetition of the "to" as a stutter, "a gap between the text and its subject" (90). While Gawron appears to offer these as two different readings, I would merge them and argue that what we see here is a spacing of consciousness. The "self" remains, during the period of this stutter, exposed, its identity somehow outside of itself and with others (Nancy IC 15). Certainly the "coming to" of consciousness and the "wounding" gesture toward the strange logic of exposure: identity remains, but it is wounded and open to others.

What this analysis reveals is that Bellona is similarly wounded. If the wound is a stutter, the spacing of consciousness, then Bellona is always already wounded before Kid arrives. Kid's subjectivity was exposed before he even set foot in the city which suggests that it is only Bellona's exposed condition that allows him entrance, and, once within, the freedom to be the singular person that he is, denying any easy assimilation to an urban project. Just as the Richards' home and work are interrupted and spaced out and into the other, so is the subjectival being that is Bellona. Bellona is unworked, profoundly resistant to the salve that would return it to full health. On the level of writing, Mr. Newboy later describes Kid's poetry as "that holy and spectacular wound which bleeds" (258). All of which suggests that what is at stake in this exposure to the death of the other is the collapse of myth. If myth can be thought of as the seamless work of creating a home and a consciousness, Bellona is exposed to the outside in the absence of a work, a myth, or oeuvre.

Delany's text adroitly answers the most obvious questions concerning this interruption of the work of myth: What does this exposure entail on a concrete level for knowledge, community, economics, and ethics? It is important to note that while a concrete description of what this exposure entails is necessary as a bridge to more central questions, it would be dan- 
gerous to not discuss each of these issues together. To discuss the theme of birth without the "being-with" of community, would be to risk falling into a subjectival reading which clearly is not my aim.

Exposure to the "being-with" of community occurs when the rational subject faces the death of an other. Bellona, correspondingly, is described as a graveyard by Kid (386). This is an apt portrayal insofar as no one is buried or, assumedly, receives the traditional burial rites and rituals. After being carried out of the elevator shaft, Bobby is left to rot in an empty apartment. I'm reminded of George Bataille's comment that "community" must remain at the "peculiar grandeur" of death, or risk falling into subjectivity (Nancy IC 16). It is such a "being-with" of finite and exposed beings that we see in Bellona. Bellona and its singularities are defined by terror: "When what terrifies is neither noisy, nor moves quickly, and lasts hours, then we become very different. I don't know who she is!" (441). Since death is unknowable and indistinct, it follows that such an experience has radical hermeneutic implications, extending even as far as Kid's inability to "know" his partner, or his own name, which many too quickly confuse with insanity. Kid describes his state in the following way:

"Look about . . . being nuts. [. . .] You're not, and you never have been. That means what you see, and hear, and feel, and think ... you think that is your mind. But the real mind is invisible: you're less aware of it, while you think, than you are of your eye while you see ... until something goes wrong with it. Then you become aware of it, with all its dislocated pieces and its rackety functioning, the same way you become aware of your eye when you get a cinder in it. Because it hurts ... Sure it distorts things. But the strange thing, the thing that you can never explain to anyone, except another nut, or, if you're lucky, a doctor who has an unusual amount of sense-stranger than the hallucinations, or the voices, or the anxiety-is the way you begin to experience the edges of the mind itself . . . in a way that other people just can't." (original's emphasis; 48)

In some ways what we have here is similar to the finite objectivity put forward by Donna Haraway in "Situated Knowledges" in which she argues against a disembodied panoptical objectivity and for an embodied objec- 
tivity. The godlike eye, she insists, "distance(s) the knowing subject from everybody and everything in the interests of unfettered power" (188). She argues for a mortal, situated knowledge which is ultimately more objective: "only partial perspective promises objective vision" (190). Such a situated and embodied objectivity is more responsible because it is there with others rather than abstracted from the world like an immanent subject created over and against an object.

The Richards family is implicated in this critique due to their obsession with moving up in their building to a nineteenth floor apartment with a balcony. The other god-like eye in Bellona is Roger Calkins, the newspaper editor, whose mansion overlooks the city. Against this notion of consciousness ("what you see, and hear, and feel, and think"), Kid points to a way of seeing founded on the interruption of this panoptical eye and, ultimately, on the death of the other described above and our consequent finitude. His argument here bears a strong resemblance to Heidegger's analysis of the broken tool (73-73; German page numbers). ${ }^{1}$ For the latter, the "I" is not absolute, self-birthed, and non-relational, but essentially with others in a way that cannot be thought ("invisible") because thought by its very nature separates the "subject" from its essence. Its essence is existence if we understand existence as the constant "self"-interpretation that occurs prior to rational consciousness and inserts us in the world in a profound referential manner (Dreyfus 12-17). Heidegger describes being-inthe-world in an imminently practical way, as "a handling, using and taking care of things which has its own kind of "knowledge" (67).

It is this being-in-the-world that is pointed to in the reference to the "real mind is invisible." Delany is not arguing for a higher mind beyond our own which would ground our world, so much as using a metaphysically bankrupt vocabulary to suggest that reality may not have a ground at all; reality may be interpretation all the way down. This "mind," then, is not normally noticed, or subject to scrutiny. As Heidegger's famous analysis of the hammer suggests, it is only when something goes wrong, when the equipment we need for a project fails, that we see the worldliness of the world. Once broken, the tool's relation ("reference") to its wielder and the world around it is made conspicuous. The state of being broken forces us to recognize our relation and dependence on the world around us, which is to say, that we are in the world and not monadic beings. During this experience, the reductive, assimilative work of rationality stalls, and 
alterity is seen as "dislocated" and "rackety." While the tool's "wounded" status-in this case, the cinder in the eye-may cause some discomfort, forcing the "subject" to be exposed to the world, to anxiety, hurt, and to mortality, this discomfort allows for a more accurate experience (or "knowledge") of the world by allowing the "subject" to "experience the edges of the mind itself." Delany underlines this a bit more concretely directly after this speech. Kid, who never wears more than one shoe, puts his bare foot on the floor and the omniscient narrator remarks, "He was far more conscious of the texture of the floorboards with the foot that had been bare" (48). Kid, like his shoes, both present and absent, has a more direct, bodily understanding of the world.

We've already seen to some degree how Mrs. Richards creates a monadic shell around her family, cutting her off from community. The text indicates this more directly when her daughter, June, visits her brother at the scorpion commune. Delany writes, "She circles [. . .] in. Yet she's so far away! It's not even that [. . . ] she's a pretty girl, but rather that there are over two dozen people living in here and the isolation she demands about her destroys our concept of human space" (563). June is god-like and "heroic," if only because of her persistence in trying to mend her family. She is visiting in order to convince her brother Eddy to return to the family which she says has "fallen apart ... it's like ... the plug was pulled out and everything ran out. All of it" (567). June is the very model of the monad insofar as she is intent on control, on a restricted economy that is intent on conserving identity, keeping it all inside (Derrida WD 251-277). Her greatest worry is precisely what we see once again in this final quotation: the horror of an inside exposed to the outside.

By contrast, for those who are exposed to one another, "Bellona is terribly hospitable. You can have your fantasy and [. . .] feel just a bit less like you're depriving anyone else of theirs" (373). While Bellona is full of wealth, little real looting occurs which is "a comment on the limits of the particular mind the city encourages. Who wants to be as lonely as the acquisition of all those objects would make them?" Rationality, in its essence, always gathers to its self, assimilating alterity. Its interruption amounts to a radical dispersal. At a party thrown in honor of Kid's recently published book, Kid notes how Calkin's mansion "can soak up a lot of people," before the conversation turns to the city: 
"How odd," Lanya said. "All the limits go, and you can't believe there's really any more to it. We're used to objects like icebergs or old wells where you know most of it is under ground or water. But something like a city at night, with great stretches of it blotted or obscured, that's very different-“"

"You guys," Denny interrupted [. . .] you two can talk about things that, you know, are just so far beyond me [. . . ] when I don't understand-even when I do, I just wanna fuckin' cry, you know?" [. . . ]

Lanya nodded. "I do."

Denny breathed out and looked.

They stood apart and felt very close. (615)

Calkins, June, and Mrs. Richards are each examples of the rational subject gathering in difference, making it work, creating a profit, and forming a narcissistic shell around the self. This shell amounts to the drawing of limits, a delineation of inside and outside, which allows identity to be seen. In Bellona, the death of the other has turned Bellona's urban consciousness, these limits, inside out. The city's condition exposes most people to their essential finitude and the impossibility of immanence. With the limits (borders, edges) of their minds turned inside out, the work of assimilation stalls and with it the capitalist impulse. Kid, by contrast to Calkins or Richards, does not depend on clear limits. Calkins is able to assimilate many people ("can soak up a lot of people") because he possesses a sense of interiority and an interior always requires an exterior with the borders in between. Exposed to death, Kid, Lanya, and Denny as subjects are interrupted and spaced out and into one another: they can stand spatially distant from one another, yet, due to this rational interruption ("so far beyond me [rationally]"), find themselves in the most intimate of situations.

This notion of intimacy is a radical revision of that seen in Delany's book-length essay, Heavenly Breakfast: An Essay on the Winter of Love. The essay concerns itself with the author's experience living in a New York commune in 1967 and 1968. While Robert Elliot Fox argues that Dhalgren describes the "cold underside" of his communal experience rather than any "hoped-for state of bliss," I would insist that both of these texts are very much concerned with the possibility of a communal, utopian 
ethics (106). In Heavenly Breakfast, space remains a concern. In a commune the quarters are so close, Delany tells us, that every action on the part of an "I" is immediately felt by others and vice versa: "the square of the distance intervening between us must be a diminishing factor in how much information and energy crosses from me to you and back" (103). Since there is such an immediate connection between people, it becomes impossible "to avoid responsibility" or force the other person to work harder than he or she can bear. All of this is communicated less through rationality ("telepathy") than "touch and smell." While Delany even at this early moment is skeptical of rationality, he does not emphasize its interruption, so much as the way that touch and smell appear to overwhelm the rational information that might bolster an "I." In Dhalgren, by contrast, he begins with an experience, the death of the other, that interrupts rationality.

* * * $\quad *$

Nancy describes how prior to myth humans existed as singularities, not linked by anything other than being-with. In an interview, he describes the concept as "proximity without recovering [assimilating] one through the other. If the pen is hidden behind the glass, you can't say they are 'with.' [. . .] So, 'with' implies proximity and distance, precisely the distance of the impossibility to come together in a common being [a subject]" ("Love and Community"). The "with" points toward the absolute impossibility of an absolute, of a subject who can be non-relational, shutting out alterity. It was only when a speaker, a poet, stood up and began telling a story that these separate singularities began to recognize each other and cohere and move toward immanence. As the scene of myth, it is also the scene of a subject's (re)presentation of itself: "Myth is of and from the origin, it relates back to a mythic foundation, and through this relation it founds itself (a consciousness, a people, a narrative)" (IC 43-45). Once the poet/hero begins speaking, "it is no longer the language of the [singular] exchanges, but of their reunion-the sacred language of a foundation and an oath." The "unknown" and unnamed become known during this telling. The group of disparate singularities knows itself and the world through this representation. Consciousness, immanence, and subjectivity are all formed through the telling of myth. 
In the case of Bellona, tremendous forces immediately begin to rework the mythic fabric whose shredding has exposed the city to beingwith. Once again, Mrs. Richards can serve as an example. After Bobby's death, she discovers Kid writing a poem and wonders if it is an elegy for Bobby. Kid denies this and immediately decides that "Elegy" will be the title (242). Mrs. Richards exudes a "nervousness" that makes others conform to her wishes (173). In this case, she uses Kid's poetry to heal her exposure to Bobby's death. On the level of the polis, Calkins stands in for Mrs. Richards. Just as Mrs. Richards tries to use Kid and his writing as a means of healing the rift created by Bobby's death, so Calkins twists reality and makes Kid a mythic hero, filling in or caulking the breach in Bellona's psyche $(654,712-713)$. Kid says, 'I'm not a poet. I'm not a hero. But sometimes I think these people will distort reality in any way to make me one-but that's insanity, isn't it?"

Calkins identifies with the city ("my City") and uses Kid, "the sort of poet Bellona needs," as a means to build up a level of "acclaim" for Bellona (658; 740-742). Calkins publishes Kid's Brass Orchids without even reading it or meeting with the poet. Society requires art, well-written or not. Calkins describes his interest in Kid as a matter of the "mechanics of power." However, he is just as interested in Kid as a hero than as a poet. If we ignore, for the moment, Dhalgren's surreal and fragmented prose and focus on the actual events of the narrative, the novel could be understood as a heroic epic, the outfitting of the hero being one of the most obvious conventions of the heroic myth. The partially amnesiac narrator enters the city and almost immediately is outfitted with "three gifts [. . .] armor, weapon, title" $(18,7)$. He is armed with an "orchid" which resembles Edward Scissorhand's famous blades. For armor, he has a three-yard long chain of prisms tightly wrapped around his torso. And, lastly, he is dubbed "the Kid," "Kidd" or "Kid." Along with these themes, we have the epic length of Dhalgren itself, the repeated mention of Kid as "hero," and the way that the novel ostentatiously thematizes myth (249). On the most blatant level, the Bellona Times continually misrepresents Kid, so that he and the scorpions look more dangerous, if not heroic. When he follows George into a burning house to rescue three children, he retains all the credit while George is dropped from the news story. When he and the scorpions go on a "run" through the city, a series of dull pranks is blown into a violent rampage. ${ }^{2}$ 
This heroic thematization is perhaps nowhere more evident than in an image that appears to Kid as he engages in a consensual gangbang with fellow scorpions:

This time, it was an image of myself, holding hands with someone (Lanya? Risa? Denny?) and running among leafless trees laced with moonlight while the person behind me kept repeating: '. . . Grendal, Grendal, Grendal ...' which, while I rocked my face in her hot neck and the stinging in my thighs, chest, and belly went on, seemed very funny. (Specific and primitive?) I raised my face out of the moonbright branches into a room lathered with the smell of smoke and scorpions. And grinning, man, like a tiger. (678)

Kid is haunted by a simultaneous call to the closely coupled vocations of hero and poet. This repetition is either the call to kill the monster Grendel, or to write the story, a contemporary Beowulf, that would recapitulate the death of Grendel - the monster in this case being a metaphor for the unworking of Bellona. As his handholding and flight indicate, heroism endangers his relation with others. This theme of myth's immanence and exclusion is underlined by the final reference to "grinning [. . .] like a tiger." Ostentatiously an allusion to the grinning and tiger-like protagonist of Alfred Bester's The Stars My Destination, it also links up with what may be the most repetitive trope for immanence in the novel: lions. Statues, or monuments, of lions are strewn throughout the text. We see them linked to Mrs. Richards, Calkins, and the park commune. In each instance they are linked to work, to the assimilative actions of the rational subject.

Matters do not remain so simple. Afterwards, Kid realizes that it was not Gren-dal, but Dhal-gren that he heard. While not stated explicitly, it seems fairly clear that Bill, the man who interviews Kid for the Bellona Times is, in fact, William Dhalgren (783). "Kid" does not know his name and wonders whether he, himself, might be William Dhalgren, whose link with the newspaper-a transmitter of myth — can only magnify the logocentric implications of the proper name. The latter would seem to be an immediate means of identifying a person through language, an identification that would not have to first traverse the outside, a relation to the other (Bennington 105). In Glas, Derrida writes that "the work of mourning 
[. . .] is always for/of the proper name," an observation that is supported very well by Mrs. Richards, among others (86). The proper name as with any other "proper" thing - property, propriety - can only be what it is through exclusion of that which is other, exclusion of that which undermines the illusion of pure immanence. Since death or a recognition of finitude leads to a radical interruption of subjectivity, subjectivity can be thought of as essentially founded on a work of mourning in which death is kept at arms length through the polite observance of funeral rites: myth, in a word. But this is impossible. When Kid once again remembers his proper name (described later in this piece), he is already "with" others in the sense I have been describing. The proper name cannot be removed from what Derrida calls the "system of differences."

The essential tension in the novel is between whether to be a hero/poet/proper name, or to be exposed to the being-with of relation. Kid waffles on this question. At the moment he realizes that he had heard "Dhalgren" and not "Grendal," he wipes himself with a copy of the Times. At this Joycean juncture, Kid does not recognize the connection between the Times and William Dhalgren, but the implicit criticism remains (679). At other moments, he is enthralled by the fantasy of the Author. Consider his ambivalent attraction to Newboy's books: "A field, cast by the name of a man, who, without my ever having read a complete work of his, the hidden machinery of my consciousness at some point decided was an artist. How comical, sad, exhausting. Why am I a victim of this magic?" (763). And yet he wonders whether he will also cast such a spell on those who have not read him.

What is at stake in this question of having a poet/hero for the city? If we ignore Delany's explicit interest in the question of community, Dhalgren could be read as an 800 page gloss on Michel Foucault's "What is an Author?" In Foucault as well, it is death that provides impetus for the creation of narrative (890). Narrative substantiates the hero's death and postpones, in the exemplary case of Scheherazade, the moment at which the poet faces death. The poet, hero, and narrative are all bound to the movement of what Foucault terms individualization which he also sees in terms of space. When the author dies, he writes, "we must locate the space left empty [...] follow the distribution of gaps and breaches, and watch for the openings that this disappearance uncovers" (892). It is less this emphasis on space that interests me, as Nancy has certainly theorized spatiality in 
more extensive ways, than the question of how the author-function operates in Dhalgren.

Clearly, in the "author" we confront the problematic of the proper name, myth, and heroism. Foucault's theorization of the author function dovetails with the above on several interrelated levels: the author acts as a limiting agent, "marking off the edges of a text" (893); the author is a "principle of thrift [read, restricted economy] in the proliferation of meaning" (899); and, the author is a "principle of unity" (895). Just as Kid is controlled by Newboy's books, so Kid operates for Bellona. Looking at Newboy's books, Kid asks, "What is it around these objects that vibrates so much the objects themselves vanish?" (763). Kid, as concrete, singular book, is also lost when the author function controls him which explains how this "hidden machinery" is also able to look past Kid as a singular entity and create him as Author. The importance of this appropriation cannot be underestimated. In a limit-less city, a city without an economy and without unity, Kid as Author represents a crucial limiting figure. Kid as Author lends himself to the city as Subject; otherwise, the city or community of Bellona, remains un-worked, a non-exclusionary being-with.

* $\quad * \quad *$

"You have received that holy and spectacular wound which bleeds . . . well, poetry [. . .] But have you hunkered down close to it, sighted through the lips of it the juncture of your own humanity with that of the race? [. . . Whether love or rage," Mr Newboy went on, not looking up, "or detachment impels the sighting, no matter. If you don't do it, all your blood is spilled pointlessly ..." (258)

We have a sense of what this "holy and spectacular wound" entails epistemologically, relationally, and economically for singularity (as opposed to subjectivity). We have also touched on the question of myth and its web of influence. In this final section, I focus on the question of writing more directly, asking how Dhalgren mitigates against a mythic, monumental state. We have a sense of what a city or knowledge might look like in light of the experience of the wound, but what about a work of art? If consciousness, subjectival or urban, is a matter of seamless myths, how 
can writing remain exposed, un-worked and thereby retain the ethical, epistemological, economic benefits detailed above? How can an author write without becoming subject to "Authority" and to the consequent assimilation of difference?

I have already mentioned the circularity of Dhalgren's narrative and alluded to some of the apocalyptic themes that are never fully narrated: the origin of Bellona's wounding, and the "plague" alluded to in two section headings ("In Time of Plagues" and "The Anathemata: a plague journal"). Dhalgren owes its horror to its absolute abandonment of these flagrantly important themes. Apart from one young woman lying sick in a bed, we are left pondering whether the plague is a real illness or existential, along the lines I have been depicting. In addition, the ontological nature of Dhalgren is confused on several levels. Dhalgren appears to be a novel concerned with Kid's experiences in Bellona in which a clear division between author and subject is cultivated. Then we begin to notice that the notebook-already full of notes and observations when given to Kid early in the text-begins to repeat the opening of the novel. Is Kid writing the "novel" before us, or has he discovered the author's discarded notebook and decided to inscribe his own thoughts alongside the author's words? The opposition between author, character, and reader are all radically displaced in this way.

Along with this stylistic intermingling of self (author) and other (his object, characters), the novel shifts point of view frequently. Most of the text remains in third person omniscient while infrequent paragraphs in the first person detail Kid's observation of the world around him. Dhalgren's most ostentatious feature is the way in which the text is riven by multiple narratives. This is particularly true of the final section, the plague journal, in which a third person narrative might take up the left portion of the page and Kid's own point of view the remaining white space. Kid's interjections often criticize the inaccuracy of the other passage, implying that he, once again, is the Author and denying any simple totalization of meaning. The text in this final section appears unfinished; words are crossed out, or sentences end in midstream. At least two editorial notations appear here by, it would seem, two different editors. We are given a profound sense of a project that has not been finished, but simply abandoned.

I want to turn to a lengthy passage in which we find Kid writing. Before turning to his notebook, Kid has been walking through the city, horri- 
fied by the inexplicable destruction he sees around him in which the "demarcation [again, limit or border] between lawn and street vanished beneath junk" (77):

He sat down on the curb, opened to the notebook's first page.

to wound the autumnal city

he read once more. Hastily he turned the page over to the clear side. He looked down the four streets, looked at the corner houses. He sucked a breath through closed teeth, clicked the point out and began to write.

In the middle of the third line, without taking pen off paper, he swept back to cross it all out. Then, carefully, he recopied two words on the next line. The second was "I." Very carefully now, word followed word. He crossed out two more lines [...]

Between lines, while he punched his pen point, his eye strayed to the writing beside his:

It is our despair at the textural inadequacies of language that drives us to heighten the structural ones toward

"Annn!' out loud. There was not a pretty word in the bunch. Roughly he turned the notebook back around the paper to avoid distraction.

Holding the last two lines in his head, he looked about at the buildings again. (Why not live dangerously?) He wrote the last lines hurriedly, notating them before they dispersed.

He printed at the top: "Brisbain"

[ . . .] closed the book, puzzled at what he had done.

Then he stood.

Struck with dizziness, he staggered off the curb. He shook his head and finally managed to get the world under him at the right angle. The back of his legs were cramped: he'd been in a near-fetal squat practically half an hour. (original's emphasis; 78-79) 
Fredric Jameson's main thesis in Postmodernism or, The Cultural Logic of Late Capitalism is "that the latest mutation in space-postmodern hyperspace-has finally succeeded in transcending the capacities of the individual human body to locate itself, to organize its surroundings perceptually, and cognitively map its position in a mappable external world" (44). Needless to say, for Jameson agency depends on the ability to cognitively map postmodern space whose confusion he links to "late capitalism." Bellona's spatial confusion cannot be overstated. We must not only recall Kid's sense that the city changes daily-he even sees one person swapping road signs - but the essential mystery of what led to this confusion remains unanswered. The passage moves from a horror of postmodern urban space to a sense of positioning seen most simply in Kid's mapping of self ("I" above) against the other. Soon after writing the poem, Kid's dizziness dissipates and with it his horror of the street. He notices that Brisbain North has given way to Brisbain South, bringing Kid (on the next page) to Calkin's mansion. Clearly, this transformation is a product of writing; writing, urban spatial mapping, and consciousness are knotted together here. All of this fittingly occurs while Kid is on his way to Calkins's mansion. In writing this poem ("Brisbain"), he has already begun to fulfill his role as mythmaker. By contrast to Jameson, however, it is the capitalist, Calkins, who pushes for this new mapping.

The passage begins with Kid glancing at the opening page of the notebook which "begins" as Dhalgren does ("to wound the autumnal city"). Kid "hastily" turns the page. When he glances to the writing adjacent to his own-an incomplete sentence which details the inadequacy of language (the impossibility of myth's desire to resolve the chasm between idea and reality) - he screams. This strange scream ("Annn!") also occurs in a flashback of his boyhood derangement. Again, he turns the notebook so he will not be "distract[ed]." We have already seen how this passage describes the creation of subjectivity as mythic mapping. Identity, as we have discussed, is a matter of non-relation, immanence. What we see here is the birth of immanence which is always formed first through relation to the other (the glance to the writing on the side) only to then hastily elide that same movement. This is a glance, a relation, that the resultant subject cannot comprehend because its birth via relation is beyond the subject: "to the degree that it occurs, birth effaces itself, and brings itself indefinitely back. Birth is this slipping away of presence through which everything 
comes to presence" (Nancy Birth 4). In this case, this birth is that of a poem, "Brisbain," which appears to have been fully completed while Kid sat in a "near-fetal squat." Kid's forgetfulness, however, reaches beyond the elision of the other in writing to the point at which his own terror dissipates, demonstrating the concomitant connection between myth and consciousness. A completed writing-unlike the fragment mentioned above- protects the subject from the horror of relation, rebuilding the limits of consciousness along with the limits of the city street.

When Kid finally remembers his name, a similar situation is played out. The scorpions and various other Bellonan people dance en masse around a fire. It is riotous. People are naked, clapping, floundering back and forth, and stumbling into one another. With the emphasis on a central point, the fire, and Kid's recollection of his name (Michael Henry Fl-) and Dhalgren's, this appears to be a celebration of immanence. Yet the center in this case is a fire, a figure for the Bellonan catastrophe, and there is a profound sense of transience in this passage. Derrida writes of cinders as "at once the best name for the absence of a truly proper name" (Lukacher 1). The fire, like ashes or cinders, signals both identity's presence and its absence-its presence in others, its relation. Paul Fenster, a civil rights worker and non-dancer, tries to keep Kid and Lanya from falling but Lanya tells him that "It's all right if we fall" (779). Protecting the self (or Calkins's mansion) is not part of this dance. This is not a restricted economy. Instead, it is a dance grounded in the movement of Being (in which, it is worth noting, both conservative (Calkins) and liberal politics (Fenster) are critiqued):

I sat and panted and smiled [. . .] with contentment over the absolute fact of his [William Dhalgren's] revealed identity, till even that, as all absolutes must, began to dissolve. [. . .]

"What-?" Denny moved his hand on my leg.

Lanya glanced at me, shifted her shoulder against mine.

But I sat back again, silent, marveling at the dissolve's completion, both elated and numbed by the jarring claps that measured and metronomed each differential in the change-till I had no more certainty of Bill's last name than I had of my own. With only the memory of knowledge, and bewilderment at whatever mechanic had, for 
minutes, made that knowledge as certain to me as my own existence, I sat, trying to sort that mechanism's failure, which had let it slip away. (784)

Their dance celebrates the stutter, the gap or relation to the other, through which entities begin their presencing. Kid strips and says, "I want to . . to dance" (782). This is not a celebration of destruction either, because that would very quickly fall into immanence. It is instead the coming and going, the birth that leads to presence. Kid is both "elated and numbed," feelings that go in divergent directions. Opposed to the deadening effect of signification, of the proper name, of myth, is the freeing movement of existence-the only "knowledge" Kid can attest to. Kid's interest in "Dhalgren" parallels the reader's. We also want to have this mystery unveiled yet, following Kid, it is not the signified that becomes privileged here, but the architecture of meaning that allows signification to appear. To privilege this coming is to privilege existence. To ex-ist is to be in relation, exposed to the outside. Signification, myth, subjectivity are what erase existence as they resolve the gap between reality and the subject's idea of what reality should be, creating the illusion of non-relation to others (Nancy Gravity 22-23; "Of Being" 1). Existence, then, is irrevocably communal or relational.

Nancy writes that "Death is the absolute signified, the sealing off of sense. It is the name, but 'to be born' is the verb" (original's emphasis; 3 Birth). Dhalgren concerns itself with birth as that which is foregrounded when myth is interrupted. "Kid" is continually being born: Kid, Kidd, the Kid, Michael Henry Fl—. Not only the instability of his name, but "Kid" signifies immaturity, if not birth. Each of the recently quoted passages are concerned with the nature of birth. In the first we saw how relation was elided in the process of writing "Brisbain." The second passage makes clear that birth, here, is not birth as signification, or the work of mourning, or heroes. Birth in the second passage is approximate with the sideways look, that relation that is quickly rejected in the writing of "Brisbain."

What would a work that included this relation look like? It would look un-worked, rather like Dhalgren whose incompleteness, abandonment, ostentatious erasures, and editorial intrusions force the reader to recognize the relation to the other that was eliminated during the writing of the poem. Dhalgren is the gap, or stutter, that which disturbs the easy assimi- 
lation of alterity to a tidy inside. There is no tidy inside here. The work of myth has been exposed, leaving the reader without a unified sign, hanging, exposed to the outside - but not without meaning. We are meaning, as Nancy likes to say. Meaning, he writes, "takes place between us and not between signifier, signified and referent [. . .] before all produced or disclosed meaning, and before all exchanges of meaning, our existence presents itself to us as meaning" (original's emphasis; Gravity 58, 62). Meaning is an "infinite hollowing out of presence" of the subject and the subject's myths: the city, the proper name, and so on (64). All that remains is that we follow Kid's lead and sit back and enjoy its coming and its going.

Perhaps here we can begin to understand the relentless sex in Dhalgren and its link to this exposed community (sex requires more than one). Unlike the traditional heterosexual coupling which the Catholic Church and others have linked to societal welfare, a threesome is not productive. After the West and its obsession with signification, it is just such an unproductive coupling that beckons to us. This new "subject comes, does nothing but come, and for him, presence in its entirety is coming: which means, not 'having come' (past participle), but a coming (the action of a coming, arriving). Presence is what is born, and does not cease being born" (Nancy Birth 2). In this way, Delany represents those strife-torn American cities of the 1960's and 1970's in a profoundly different light. If Bellona stands in for one of these cities, it does not represent a simple tragedy-a monument - that a liberal or conservative politics could then be founded upon. Instead, Delany peels away these exclusionary structures and represents what cannot be mentally represented: our birth which always takes place with others, a birth both horrifying and wonderful.

Jean-Francois Lyotard describes the Paris riots of 1968 in a similar fashion by showing how politics grounds itself in forgetting. Polemos exists between conservatives and liberals as a way to forget this birth that "has no relation to the mind" but gives birth to the mind (44). Conservative and liberal politics are equivalent insofar as each tries to assimilate the "unmanageable" (birth, death), that which cannot be used as a basis for a conventional community. He describes the student protestors as lacking a "contract" (a political agenda), and, as such, dwelling within that childhood, or state of dependency that the adult mind-obsessed with immanence-cannot bear. Such a "politics" confronts traditional authorities 
with their essential relation to others. Dhalgren, in this way, has much to say about the nature of black, gay and even feminist politics of the late 1960 's and the early 1970's.

Monuments - to return to our introductory theme-are also born. In Dhalgren's strange opening pages, Kid meets a woman outside of Bellona, makes love, asks if she knows his name (she says, "You've come from somewhere. You're going somewhere" as if that is all the identity one needs), and then chases her until she transforms into a tree $(4,2)$. Again, the proper name, the name that would be a monument, is juxtaposed with birth, the dryadic transformation. However, it is not until much later that we learn that this "Eurasian" had built a "life-size lion wedged together out of scrap car-parts and junked iron" (785). She is a bricoleur, as opposed to an engineer. An engineer, like Mr. Richards, is one who would "supposedly be the absolute origin of his own discourse and supposedly would construct it 'out of nothing"" (Derrida WD 285). An engineer would create a lion without seams, non-relational, like the lions found in Mrs. Richard's apartment or guarding Calkins's mansion. A bricoleur does not dabble in theology, but takes her concepts from a "heritage which is more or less coherent or ruined." Ruined, heterogeneous, abandonedit is just such a monument that Dhalgren plays at being.

\section{Notes}

The author thanks Maureen Lauder, Dawn Comer, and JNT's anonymous reader for their many incisive comments on earlier drafts of this essay.

1. If it were not for the centrality of mourning in the novel and this resemblance to a passage in Heidegger's Being and Time, I might have led with the following. Ken James writes, "Delany argues that the rhetoric of science fiction foregrounds precisely the historical, social, and technological constitution of human landscapes which conservative rhetoric tends to obscure" (James xix-xx). Rather than being naturalized or dehistoricized and thereby elided, the objective world (of space, landscape, culture, and technology) are foregrounded as questions in sf.

2. Both Gawron and Mary Kay Bray have produced intriguing takes on Delany's use of myth. Bray writes, "By means of its ironies, Dhalgren brings readers to a simultaneous awareness both of traditional American myths and preoccupations and of their failure to be viable, at least for some [. . .] ironies in Dhalgren emanate from the pattern of 
quest and initiation suggested above, from a variety of plays upon the concept of American individualism, and from a thirst for moral absolutes set against an intensely relative background" (58).

\section{Works Cited}

Bennington, Geoffrey, and Jacques Derrida. Jacques Derrida. Chicago: U of Chicago P, 1993.

Bray, Mary Kay. "Rites of Reversal: Double Consciousness in Delany's Dhalgren.” Black American Literature Forum. 18.2 (1984) 57-61.

Delany, Samuel R. Dhalgren. New York: Vintage Books, 2001.

Heavenly Breakfast: An Essay on the Winter of Love. Flint, MI: Bamberger Books, 1999.

Derrida, Jacques. Writing and Difference. Trans. Alan Bass. Chicago, Ill.: U of Chicago P, 1978.

. Glas. Trans. John P. Leavey, Jr. and Richard Rand. Lincoln, Nebraska: U of Nebraska P, 1990.

Dreyfus, Hubert. Being-in-the-World. London, England: MIT Press, 1997.

Edelman, Scott. "Samuel R. Delany exposes the heart of Dhalgren over a naked lunch." Science Fiction Weekly Review. 18 June 2001. 8 July 8, $2004<\mathrm{http} / / /$ www.scifi.com /sfw/issue217/interview.html>.

Fox, Robert Elliot. "'This You-Shaped Hole of Insight and Fire:' Meditations on Dhalgren." Ash of Stars: On the Writing of Samuel R. Delany. Ed. James Sallis. Jackson, Mississippi: U of Mississippi P, 1996. 97-108.

Foucault, Michel. "What is an Author?" The Critical Tradition: Classic Texts and Contemporary Trends. Ed. David Richter. Boston, Mass.: Bedford Books, 1998. 889-900.

Gawron, Jean Mark. “On Dhalgren.” Ash of Stars: On the Writing of Samuel R. Delany. Ed. James Sallis. Jackson, Mississippi: University of Mississippi Press, 1996. 62-96.

Haraway, Donna. Simians, Cyborgs, and Women: The Reinvention of Nature. New York: Routledge, 1991. 
Heidegger, Martin. Being and Time. Trans. Joan Stambaugh. Albany, New York: SUNY P, 1996.

James, Ken. Introduction. Longer Views: Extended Essays. By Samuel R. Delany. Hanover, New England: Wesleyan UP, 1996.

Jameson, Fredric. Postmodernism or, The Cultural Logic of Late Capitalism. Durham, North Carolina: Duke UP, 1999.

Lukacher, Ned. "Introduction: Mourning Becomes Telepathy." Cinders. By Jacques Derrida. London: U of Nebraska P, 1991. 1-18.

Lyotard, Jean-Francois. "A L'insu (Unbeknownst)" Community at Loose Ends. Minnesota: U of Minnesota P, 1991. 42-48.

Nancy, Jean-Luc. The Inoperative Community. Trans. Peter Connor. Minnesota: U of Minnesota $\mathrm{P}, 1991$.

—. The Birth to Presence. Trans. Brian Holmes et al. Stanford, California: Stanford UP, 1993.

The Gravity of Thought. Trans. Francois Raffoul and Gregory Recco. New Jersey: Humanities Press, 1987

. "Of Being-in-Common." The Community at Loose Ends. Ed. Miami Theory Collective. Minnesota: U of Minnesota P, 1991.

. "Love and Community: A round-table discussion with Jean-Luc Nancy, Avital Ronell and Wolfgang Schirmacher." The European Graduate School. Aug. 2001. 20 Aug. 2004. <http://www.egs.edu/faculty/nancy/nancy-roundtable-discussion 2001. html>.

Zinn, Howard. A People's History of The United States: 1492-Present. New York: Perennial Classics, 2001. 